Original Research Paper

\title{
Effect of Check Delay Time Difference on Enumerating Bacteria in Patients with Urinary Tract Infection
}

\author{
Inayah Fitri ${ }^{1}$, Zulfikran Moh Rizki Aziz ${ }^{2}$, Devis Ika Widyawati ${ }^{2}$ \\ ${ }^{1}$ Program Studi Biologi, Universitas Billfath, Lamongan, Jawa Timur, Indonesia \\ ${ }^{2}$ Teknologi Laboratorium Medis, Institut Ilmu Kesehatan bhakti Wiyata, Kediri, Jawa Timur, Indonesia
}

\author{
Article History \\ Received : August $06^{\text {th }}, 2021$ \\ Revised : August $28^{\text {th }}, 2021$ \\ Accepted : September 05 ${ }^{\text {th }}, 2021$ \\ Published : September $15^{\text {th }}, 2021$
}

*Corresponding Author:

Inayah Fitri,

Program Studi Biologi,

Universitas Billfath, Lamongan,

Jawa Timur, Indonesia;

Email: inayahf570@gmail.com

\begin{abstract}
Urinary Tract Infection (UTI) is a contamination in the urinary tract is often caused by bacteria. The count of number bacteria must be used in fresh urine. Using postponed urine can cause bacteria in the urine to increase. The purpose of the research was to determine the number of bacteria; severity of UTI based on the number; and the effect of variation in the length of delay in urine examination on the number of bacteria. This research used the purposive sampling method with criteria for patients who did not receive antibiotics treatment. The urine sample was postponed for 1 , 2,3 , and 4 hours at room temperature and then scratched in CLED media; after 18 hours of incubation, the number of bacteria is calculating. The results showed based on the One Way ANOVA test known that every postponed variation of examination has an influence on the number of bacteria in the urine, test of post hoc tukey showed that has real different in every postponed variation of examination. The conclusion in this study is that the number of bacteria with time postponed period variation of examination showed that there is increasment increasing $\geq 105 \mathrm{CFU} / \mathrm{ml}$, the level of severity and postponed examination assessment having influence toward influencing the amount number bacteria.
\end{abstract}

Keywords: UTI; Urine; Postponed examination; Room temperature

\section{Pendahuluan}

Pada pasien penderita Infeksi Saluran Kemih (ISK) di saluran ginjal, ureter, kandung kemih, dan uretra sering terjadi kontaminasi yang disebabkan oleh bakteri (Brusch, et al. 2016). Bakteri patogen yang bisanya dijumpai pada pasien ISK yaitu golongan bakteri Gram negatif seperti Escherichia coli, Proteus sp., dan Klebsiella sp., sedangkan dari bakteri Gram positif seperti Staphylococcus aureus, Enterococcus faecalis, dan Streptococci grup B. Pada tahun 2007, berdasarkan data dari Centers for Disease Control and Prevention (CDC), sejumlah 8,6 juta pasien ISK yang membutuhkan rawat jalan (CDC, 2011). Menurut survei demografi yang dilakukan oleh Departemen Kesehatan RI (2014) menunjukkan bahwa pasien ISK mencapai 90-100 kasus tiap 100.000 penduduk pertahun, hal ini mengakibatkan angka kejadian ISK di Indonesia tergolong tinggi (Wilianti, 2009). Angka kejadian ISK yang tinggi tidak menutup kemungkinan akan mempengaruhi tahapan pemeriksaan. Pada saat akan melakukan pemeriksaan urin, harus segara dilaksanakan karena penundaan pemeriksaan dapat menyebabkan bakteri dalam urin berkembangbiak, yang mengakibatkan koloni yang tumbuh tidak menunjukkan jumlah bakteri sebenarnya pada saat pengambilan di awal (Grabe, et al. 2015). Menurut Gandasoebrata (2013), pemeriksaan biakan urin harus segera dilakukan sebelum 1 jam setelah pengambilan.

Penelitian yang dilakukan Hidnman, et al. (1976) menunjukan bahwa penundaan pemeriksaan urin selama 6 jam pada suhu ruang mengalami peningkatan $\left(>10^{5} \mathrm{CFU} / \mathrm{ml}\right)$. Penelitian lainnya yang dilakukan Sirait (2017) menunjukkan bakteri berjumlah $75.050 \mathrm{CFU} / \mathrm{ml}$ pada penundaan 6 jam terjadi peningkatan menjadi $128.000 \mathrm{CFU} / \mathrm{ml}$ pada penundaan selama 12 jam, dan saat penundaan 18 jam jumlah bakteri mulai mengalami penurunan menjadi 80.750 $\mathrm{CFU} / \mathrm{ml}$ kemudian mejadi $78.900 \mathrm{CFU} / \mathrm{ml}$ pada 
penundaan 24 jam. Sama halnya dengan penelitian Fitri, dkk (2019) menyatakan bahwa rata-rata jumlah koloni bakteri dalam sampel urin penderita ISK mengalami peningkatan di setiap variasi penundaan pemeriksaan, tepatnya pada penundaan pemeriksaan ke-6 jam. Penundaan pemeriksaan ini sering terjadi diakibatkan oleh banyaknya sampel di laboratorium yang harus diperiksa, sehingga mengakibatkan hasil yang didapatkan seringkali tidak sesuai dengan kondisi klinis dari pasien tersebut.

\section{Bahan dan Metode}

\section{Tempat \& Waktu}

Tempat pengambilan sampel dilakukan di Rumah Sakit Aura Syifa Kediri. Tempat penelitian dilaksanakan di Labolatorium Bakteriologi dan Instrumentasi Institut Ilmu Kesehatan Bhakti Wiyata Kediri. Waktu penelitian dilaksanakan mulai bulan Oktober 2018 hingga Juni 2019.

\section{Alat \& Bahan}

Adapun beberapa alat yang digunakan dalam penelitian yaitu Erlenmeyer, timbangan analitik, cawan Petri, gelas ukur, autoclave, oven, colony counter, pot urin, sengkelit terkalibrasi, dan inkas. Bahan yang digunakan pada penelitian ini yaitu sampel urin pasien ISK, media CLED, spirtus, alumunium foil, dan urin porsi tengah pasien ISK yang telah memenuhi syarat kriteria inklusi dan ekslusi. Kriteria inklusi yaitu urin tidak mengalami penambahan pengawet, urin tidak lebih dari 1 jam, pasien telah mengisi informed consent. Kriteria eksklusi yaitu sedang menerima pengobatan antibiotik dan menolak dijadikan sebagai subjek penelitian.

\section{Teknik Sampling, Variabel \& Desain Penelitian}

Adapun Pengambilan sampel dalam penelitian menggunakan teknik Purposive Sampling, ialah teknik sampling yang berdasarkan pada pertimbangan tertentu yang dibuat peneliti (Notoadmojo, 2012). Desain penelitian menggunakan Pre Experimental Design dengan pendekatan atau rancangan Static Group Comparation, yaitu kelompok yang digunakan untuk penelitian, terbagi menjadi dua yaitu setengah kelompok bersifat eksperimen dengan adanya perlakuan dan setengah untuk kelompok control yaitu tanpa perlakuan (Sugiyono, 2016). Variabel bebas dalam penelitian merupakan penundaan pemeriksaan selama jam ke-1, 2, 3, dan 4. Variabel terikat pada penelitian yaitu jumlah bakteri pada urin penderita ISK.

\section{Tahapan Penelitian}

Dalam penelitian ini terdapat dua tahapan yaitu pengambilan sampel urin porsi tengah sesuai dengan aturan (Permenkes 2013) dan perhitungan jumlah bakteri sesuai dengan (Vandepite et al. 2010; Chenari et al., 2012; Liofilchem, 2015) setelah dilakukan penundaan.

\section{Analisis Data}

Hasil hitung jumlah bakteri dari setiap variasi lama penundaan pemeriksaan menggunakan One Way ANOVA untuk mengetahui perbedaan rerata. Apabila hasil uji One Way ANOVA menunujukan perbedaan rerata yang bermakna maka dilanjutkan ke uji post hoc Tukey.

\section{Hasil dan Pembahasan}

\section{Rata-Rata Jumlah Bakteri Setiap Variasi Lama Penundaan Pemeriksaan}

Urin yang telah diperoleh langsung dilakukan pemeriksaan jam ke-0 sebagai kontrol, kemudian dilakukan pemeriksaan pada spesimen penundaan jam ke-1, 2, 3, dan 4. Hasil penghitungan jam ke-0, 1, 2, 3, dan 4 menunjukan jumlah bakteri pada setiap sampel adalah $\geq 10^{5}$ $\mathrm{CFU} / \mathrm{ml}$, dari hasil ini dapat diketahui bahwa pasien menderita ISK dengan derajat keparahan berat. Setelah itu dilakukan perhirungan rerata bakteri dalam satuan $\left(10^{5} \mathrm{CFU} / \mathrm{ml}\right)$ untuk mengetahui perbedaan keempat perlakuan penundaan, hasil perhitungan bisa dilihat pada Tabel 1.

Tabel 1. Nilai Rerata bakteri pada setiap variasi Lama Penundaan Pemeriksaan

\begin{tabular}{|r|c|c|c|}
\hline NO & $\begin{array}{l}\text { Penundaan } \\
\text { Jam Ke- }\end{array}$ & $\begin{array}{c}\text { Jumlah } \\
\text { Sampel }\end{array}$ & $\begin{array}{c}\text { Nilai Rerata } \\
\text { Bakteri } \\
\left(\mathbf{1 0}^{5} \text { CFU/ml }\right)\end{array}$ \\
\hline 1 & 0 & 6 & 1,43 \\
\hline 2 & 1 & 6 & 1,68 \\
\hline 3 & 2 & 6 & 1,88 \\
\hline
\end{tabular}




\begin{tabular}{|l|l|l|l|}
\hline 4 & 3 & 6 & 2,13 \\
\hline 5 & 4 & 6 & 2,36 \\
\hline
\end{tabular}

Pada Tabel di atas menunjukkan bahwa ada perbedaan nilai rerata hasil pemeriksaan penundaan jam ke-0 (kontrol), ke-1, 2, 3, dan 4. Semakin lama penundaan pemeriksaan, maka rerata jumlah bakteri semakin meningkat dalam satuan $10^{5} \mathrm{CFU} / \mathrm{ml}$. Setelah diketahui rerata jumlah bakteri, maka dilanjutkan analisis statistik diawali dengan uji normalitas (Tabel 2) dan homogenitas data (Tabel 3). Hasil nilai signifikansi uji normalitas dan homogeneitas yaitu nilai sig > 0,05, menunjukan bahwa data terdistribusi normal dan homogen, sehingga data dapat diuji dengan One Way ANOVA. Uji One Way ANOVA (Tabel 4) dilakukan untuk melihat seberapa jauh pengaruh penundaan sampel urin terhadapa jumlah bakteri pada setiap variasi.

Tabel 2. Uji Normalitas

\begin{tabular}{|l|c|r|}
\hline Penundaan Pemeriksaan & Df & Sig. \\
\hline Kontrol & 6 &, 672 \\
\hline Penundaan jam pertama & 6 &, 700 \\
\hline Penundaan jam kedua & 6 &, 977 \\
\hline Penundaan jam ketiga & 6 &, 617 \\
\hline Penundaan jam keempat & 6 &, 605 \\
\hline
\end{tabular}

Tabel 3. Uji Homogenitas

\begin{tabular}{|c|c|c|c|}
\hline $\begin{array}{l}\text { Leavene } \\
\text { Statistic }\end{array}$ & df1 & df2 & Sig. \\
\hline 1,352 & 4 & 25 & ,279 \\
\hline
\end{tabular}

Tabel 4. Uji ANOVA

\begin{tabular}{|c|c|c|c|c|c|}
\hline & $\begin{array}{l}\text { Sum of } \\
\text { Squares }\end{array}$ & $\mathbf{d f}$ & $\begin{array}{l}\text { Mean } \\
\text { Square }\end{array}$ & $\mathbf{F}$ & Sig \\
\hline $\begin{array}{l}\text { Betwee } \\
\text { n } \\
\text { Groups }\end{array}$ & 31804,800 & 4 & 7951,200 & $\begin{array}{r}161 \\
, 85 \\
1\end{array}$ &, 000 \\
\hline $\begin{array}{l}\text { Within } \\
\text { Groups }\end{array}$ & 1228,167 & 25 & 49,127 & & \\
\hline Total & 33032,967 & 29 & & & \\
\hline
\end{tabular}

Berdasarkan uji One Way ANOVA (Tabel 4) dengan tingkat kesalahan 5\% diperoleh nilai signifikasi sebesar 0,000, menunjukkan penerimaan $\mathrm{H}_{1}$ karena nilai sig. $<0,05$. Kemudian dilanjutkan dengan uji post hoc tukey, dengan tujuan untuk menunjukkan beda nyata pada setiap variasi penundaan pemeriksaan.

\section{Penggolongan Kaparahan \\ Berdasarkan \\ Derajat}

Pada penelitian ini menggunakan metode urin kultur, pemeriksaan urin pada jam ke-0 (kontrol), menunjukan jumlah bakteri pada setiap sampel adalah $\geq 10^{5} \mathrm{CFU} / \mathrm{ml}$, jika dibandingkan dengan Guidelines on Urological Infection, semua sampel yang diperiksa mengalami ISK dengan derajat keparahan yang berat, namun pemeriksaan penunjang seperti leukosit dalam urin juga harus menunjukkan $\geq 10$ sel darah putih per high-power field (400×) untuk sampel urin yang disentrifugasi. Pemeriksaan dipstik dapat digunakan untuk pemeriksaan rutin, seperti uji leukosit esterase, hemoglobin, dan reaksi nitrit. Pada ISK komplikata, biasanya juga ditemui adanya penyakit dasar. Adapun bakteri yang sering ditemukan yaitu bakteri Gram negatif seperti E. coli, Proteus, Klebsiella, Pseudomonas, Serratia, dan Enterococci (Mittal, et al 2009; Seputra, et al. 2015; Bharara et al., 2017).

\section{Korelasi Penundaan Pemeriksaan dengan Jumlah Bakteri}

Penelitian yang telah dilaksanakan didukung juga dengan penelitian Dewanti dkk (2019), menunjukkan bahwa terdapat pengaruh penundaan pemeriksaan ke-3 jam terhadap jumlah leukosit urine pada pasien ISK. Begitu juga dengan penelitian yang dilakukan oleh Nugraha et al., (2019), dalam penelitiannya menunjukkan lamanya sentrifugasi sampel urine berpengaruh terhadap hasil pemeriksaan sedimen leukosit urine pada penderita ISK, hal ini dikarenakan banyaknya endapan sedimen yang terbentuk akibat proses sentrifugasi dan tingginya jumlah leukosit.

Hasil penundaan pemeriksaan urin pada setiap variasi menunjukkan adanya peningkatan jumlah bakteri, hal ini dipengaruhi oleh komposisi yang ada dalam urin. Urin merupakan cairan berisi zat-zat sisa metabolisme tubuh, seperti protein, garam terlarut seperti Natrium $\left(\mathrm{Na}^{+}\right)$dan bahan organik berupa Nitrat $\left(\mathrm{NO}_{3}\right)$ yang dikeluarkan melalui sistem urinaria (Santos et al., 2007; Purnomo and Untung, 2016). Bahanbahan tersebut bisa menjadi nutrisi atau media pertumbuhan, sehingga bakteri dapat tumbuh dan berkembang. Selain nutrisi, suhu urin yang berkisar $32^{\circ} \mathrm{C}-38^{\circ} \mathrm{C}$ juga mendukung 
pertumbuhan bakteri, karena metabolisme bakteri semakin cepat (Krihariyani, 2010). Kandungan nutrisi dan suhu urin dapat menyebabkan bakteri bertambah banyak jika dilakukan penundaan pemeriksaan. Berdasarkan penelitian yang dilakukan oleh Hidnman, et al. (1976) bahwa urin dapat menjadi medium pertumbuhan yang bagus bagi bakteri, karena mengadung material organik dan anorganik yang berfungsi sebagai sumber energi dan nutrisi bagi bakteri.

Hasil penelitian, menunjukan peningkatan jumlah bakteri pada setiap spesimen urin yang dilakukan penundaan pemeriksaan. Peningkatan jumlah bakteri pada variasi penundaan pemeriksaan jam ke-1 sampai ke-4, menunjukan bahwa perkembangan bakteri sedang berada pada fase eksponensial, yaitu jumlah nutrisi yang terdapat pada urin berada dalam jumlah banyak sehingga perkembangbiakan bakteri terjadi secara terus menerus (Chappuccino, et al., 2013; Rezai et al., 2016). Penelitian yang dilakukan oleh Hidnman, et al. (1976) juga menunjukan adanya peningkatan jumlah bakteri dengan penundaan pemeriksaan urin selama 4-6 jam pada suhu ruang mengalami peningkatan $\left(>10^{5}\right.$ $\mathrm{CFU} / \mathrm{ml}$ ). Penelitian lainnya yang dilakukan Sirait (2017) menunjukkan pada penundaan 6 jam bakteri berjumlah $75.050 \mathrm{CFU} / \mathrm{ml}$ terjadi peningkatan menjadi $128.000 \mathrm{CFU} / \mathrm{ml}$ pada penundaan $12 \mathrm{jam}$, dan saat penundaan $18 \mathrm{jam}$ jumlah bakteri mulai mengalami penurunan menjadi $80.750 \mathrm{CFU} / \mathrm{ml}$ kemudian mejadi 78.900 CFU/ml pada penundaan 24 jam.

Pada penelitian ini menggunakan Analisis data SPSS. Berdasarkan uji One Way ANOVA dengan tingkat kesalahan $5 \%$ diperoleh nilai signifikasi sebesar 0,000 pada semua sampel penelitian, nilai ini $<0,05$ yang menerima $\mathrm{H}_{1}$, sehingga dapat diartikan bahwa setiap variasi penundaan pemeriksaan memiliki pengaruh terhadap jumlah bakteri. Uji post hoc tukey sebagai uji lanjutan One Way ANOVA dilakukan untuk mengetahui beda nyata dari setiap perlakuan.

\section{Kesimpulan}

Berdasarkan Penelitian yang berjudul "Pengaruh Perbedaan Waktu Penundaan Pemeriksaan Terhadap Jumlah Bakteri Pada
Pasien Penderita Infeksi Saluran kemih" disimpulkan bahwa jumlah bakteri pada sampel dengan variasi lama penundaan menunjukan peningkatan dengan jumlah $\geq 10^{5} \mathrm{CFU} / \mathrm{ml}$; tingkat keparahan berdasarkan pemeriksaan jam ke-0, 1 , 2, 3, dan 4 menunjukan bahwa semua sampel mengalami derajat keparahan berat; dan penundaan pemeriksaan memiliki pengaruh terhadap jumlah bakteri dalam sampel urin.

\section{Ucapan terima kasih}

Dalam penelitian ini, kami berterima kasih pada pihak RS Aura Syifa dalam hal pengambilan sampel urin pasien penderita ISK.

\section{Referensi}

Bharara, T., Abha S., Renu G., Shalini D. D., Pragnya P. J., \& Avinash K. (2017). Predictive Role of Proteinuria in Urinary Tract Infection. Journal of Clinical and Diagnostic Research. Vol. 10 (11): 1-3. DOI:

http://www.jcdr.net/articles/PDF/10720/2 9615_180917_29615_CE(RA1)_F(T)\%2 0(1) PF1-(BT SS)\%20PFA(BT MJ PY).pdf

Brusch, J.L., Cunha B.A., Tessier J.M., \& Bavaro M.F. (2016). Cystitis in Females. Drugs and Diseases. https://openaccessebooks.com/urinarytract/urinary-tract-infections-andtreatment.pdf (Accessed on August 3, 2021)

Cappuccino, J. G., \& Sherman, N. (2013). Manual Laboratorium Mikrobiologi. Jakarta: EGC.

Centers for Disease Control and Prevention (CDC). (2011). Ambulatory Medical Care Utilization Estimates for 2007. Edisi 13. U.S. Department Of Health And Human Services. Washington.

Chenari, Mohsen R., Shahram, G., Amin, Z., \& Faramarz F. (2012). Assessment of Urine Analysis Diagnostic Role: A CrossSectional Study in South Eastern of Iran. 
Journal of Urology. Vol. 2: 227-231. DOI: http://dx.doi.org/10.4236/oju.2012.24041

Departemen Kesehatan Republik Indonesia (Depkes RI). (2014). Survei Demografi dan Kesehatan Indonesia. Depkes RI. Jakarta.

Dewanti, Bunga, I Gusti A. D. S., \& Burhanuddin (2019). Pengaruh Penundaan Pemeriksaan Urin Terhadap Jumlah Leukosit Pada Penderita Infeksi Saluran Kemih. Meditory: The Journal of Medical Laboratory. 7 (1), 7-12. DOI: http://www.poltekkes-denpasar.ac.id/wpcontent/uploads/2018/12/AE4.31.pdf.

Fitri Inayah., Triffit I., \& Diva N W. (2019). Pengaruh Variasi Lama Penundaan Pemeriksaan Terhadap Enumerasi Bakteri Pada Urin Penderita Infeksi Saluran Kemih. Jurnal Biologi dan Pembelajarannya, 6 (2): 12-15. DOI: https://ojs.unpkediri.ac.id/index.php/biolo gi/article/view/14793

Gandasoebrata, R. (2013). Penuntun Laboratorium Klinik. Edisi 16. Jakarta: Dian Rakyat.

Grabe, M., Bartoletti, R., Bjerklund, J. (2015). Guidelines on Urological Infections. Europa: European Association of Urology. https://uroweb.org/wpcontent/uploads/19-Urologicalinfections LR2.pdf (Accessed on August 3, 2021)

Hidnman, R., Tronic, Bruce, Bartlett, \& Raymond (1976). Effect of Delay on Culture of Urin. Journal of Clinical Microbiology, 1(4), 102-103. DOI: https://journals.asm.org/doi/pdf/10.1128/j cm.4.1.102-103.1976

Krihariyani, D. (2010). Pengaruh Penyimpanan Urin Kultur pada Suhu $2^{\circ} \mathrm{C}-8^{\circ} \mathrm{C}$ Selama Lebih dari 24 jam Terhadap Pertumbuhan Bakteri. Jurnal Penelitian Kesehatan Forikes, $\quad 1 \quad$ (2). $\quad$ DOI: https://scholar.google.com/citations?view op=view citation \&hl=id\&user=sPvdvOI AAAAJ\&citation for view $=$ SPvdvOIAA AAJ:UeHWp8X0CEIC

Liofilchem (2015). CLED / Mac Conkey Bi-plate for the isolation, enumeration and identification of pathogenic bacteria from urin specimens. http://www.liofilchem.net/login/pd/ifu/18 502_IFU.pdf (Accessed on August 3, 2021)

Mittal, R., Aggarwal, S., Sharma, S., Chhibber, S., \& Harjai, K. (2009). Urinary Tract Infections Caused By Pseudomonas Aeruginosa: a Minireview. Journal Infect Public Health, 2, 101-111. DOI: https://core.ac.uk/download/pdf/8252867 7.pdf

Notoatmodjo, S. (2012). Metodelogi Penelitian Kesehatan. Jakarta: Rineka Cipta.

Nugraha, Chairil., Ardiansah Hasin., \& Hijral Aswad. (2019). Pengaruh Lama Sentrifugasi Sampel Urine Terhadap Hasil Pemeriksaan Sedimen Lekosit Urine Pada Penderita Infeksi Saluran Kemih (ISK) di Laboratorium D-III Analis Kesehatan Universitas Indonesia Timur. Jurnal Media Laboran. 9 (2): 6-12. DOI: https://uit.e-

journal.id/MedLAb/article/download/564/ $\underline{419}$

Peraturan Menteri Kesehatan Republik Indonesia Nomor 43 Tahun (2013) Penyelenggaraan Laboratorium yang Baik. 14 Juni 2013.Berita Negara Republik Indonesia Tahun 2013 Nomor 1216. Jakarta.

Purnomo, A. D., \& Untung, T. (2016). Sensitivity and Specificity of Urinalysis to Diagnose UTI in Patient with Urolithiasis Sardjito General Hospital. Indonesian Journal of Urology. Vol. 23 (2): 130-134. DOI: http://juri.urologi.or.id/juri/article/view/2 $\underline{47}$ 
Rezai, S., Richard G., Stephen L., Sri G., Hasan N., Rahul K., Dilfuza N., Tia W., Ray M., \& Cassandra E. H. (2016). Detection of Urinary Tract Infection (UTI) and asymptomatic bacteriuria using urinalysis parameters, a review. Obstetrics \& Gynecology International Journal. 4 (2): 1-6.

DOI: https://medcraveonline.com/OGIJ/OGIJ04-00104.pdf

Santos Juliana, Conrad, dos., Liliana, P. W., \& Leandro, R. R. P. (2007). Evaluation of Urinalysis Parameters to Predict UrinaryTract Infection. The Brazilian Journal of Infectious Diseases. 11(5):479-481. DOI: https://www.scielo.br/j/bjid/a/XJsLrcVG Bt89BdXpjLmHmvJ/?lang=en

Seputra, K. P., Tarmono., Noegroho, B. S., Mochtar, A. C., Wahyudi, I., Renaldo, J., Hamid, A. R. A. H., Yudiana, I. W., ... \& Ghinorawa, T. (2015). Penatalaksanaan Infeksi Saluran Kemih dan Genitalia Pria 2015. Surabaya: Ikatan Ahli Urologi Indonesia.

http://repository.unair.ac.id/95461/1/Buku \%20gl-isk-2015.pdf (Accessed on August 3, 2021)

Sirait, R. (2017). Penundaan Pemeriksaan Kultur Urin Pasien dengan Penyimpanan Menggunakan Coolbox pada Pertumbuhan Bakteri di RSUP Dr. Kariadi Semarang. KTI. Fakultas Keperawatan dan Kesehatan, Universitas Muhamadiah Semarang. http://repository.unimus.ac.id/id/eprint/44 9 (Accessed on August 3, 2021)

Sugiyono (2016). Metode penelitian kuantitatif, kualitatif, dan $R \& D$. Bandung: Alfabeta.

Vandepite, J., Verhaegen, J., Engbaek, K., Rohner, P., Poit, P., \& Heuck, C.C. (2010). Prosedur Laboratorium Dasar untuk Bakteriologi Klinis. Jakarta: EGC.

Wilianti, N.P. (2009). Rasionalitas Penggunaan Antibiotik Pada Pasien Infeksi Saluran Kemih Pada Bangsal Penyakit Dalam Di
Rsup Dr.Kariadi Semarang Tahun 2008. KTI. Fakultas Kedokteran, Universitas Diponegoro.Semarang. http://eprints.undip.ac.id/8075/ (Accessed on August 3, 2021) 